\title{
Bioelectric characteristics of Chara fragilis (Characeae) cells
}

\author{
Aynur E. HASANOVA ${ }^{1}$, Nagi A. MUSAYEV ${ }^{2}$ \\ ${ }^{1}$ Institute of Botany, Azerbaijan National Academy of Sciences \\ 40 Badamdar Highway, Baku AZ1004, Azerbaijan \\ ahasanova89@gmail.com \\ ${ }^{2}$ Department of Biophysics and Molecular Biology, Baku State University \\ 23 Academic Zahid Khalilov Str., Baku AZ1148, Azerbaijan \\ nagi.musayev@hotmail.com
}

Hasanova A.E., Musayev N.A. 2020. Bioelectric characteristics of Chara fragilis (Characeae) cells. Ukrainian Botanical Journal, 77(5): 398-404.

\begin{abstract}
For the first time the data on the distribution of the potential $\left(\varphi_{\mathrm{m}}\right)$ and resistance $\left(\mathrm{R}_{\mathrm{m}}\right)$ in the plasma membrane and cell wall $\left(\mathrm{R}_{0}\right)$ of Chara fragilis cells were obtained using the Hogg method by the number of $C$. fragilis cells in standard conditions. The Hogg method allows simultaneous measurement of electrophysiological parameters, such as $\varphi_{\mathrm{m}}$ and $\mathrm{R}_{\mathrm{m}}$. The stationary values of the membrane potential and resistance varied in a rather wide range: $-90 . .-300 \mathrm{mV}$ and $1.0-32.6 \mathrm{Ohm} \cdot \mathrm{m}^{2}$, respectively. The average values of $\varphi_{\mathrm{m}}$ were $-183.0 \pm 4.9 \mathrm{mV}, \mathrm{R}_{\mathrm{m}}-9.0 \pm 1.2 \mathrm{Ohm} \cdot \mathrm{m}^{2}$. Using standard modifiers of membrane transport, the electrogenic activity of the cells was differentiated into two types: $\mathrm{K}^{+}$-channels and $\mathrm{H}^{+}$-membrane pumps. The activation ranges of the $\mathrm{K}^{+}$-inward rectifying channels and $\mathrm{K}^{+}$-outward rectifying channels are $-130 \ldots-50$ and $-300 \ldots-162 \mathrm{mV}$, respectively. The cytosolic activity of $\mathrm{K}^{+}$-ions was $61.6 \mathrm{mmol} / \mathrm{L}$. Since in our research, $C$. fragilis cells were studied for the first time, their electrogenic activity and ionic conductivity were tested using ammonium metavanadate $\left(\mathrm{VO}_{3}^{-}\right)-$a proton pump inhibitor and tetraethylammonium $\left(\mathrm{TEA}^{+}\right)-$a universal blocker of $\mathrm{K}^{+}$-channels of plasma membranes. Chara fragilis cells can be recommended as a test object for establishing the mechanisms of changes in plasma membrane transport under exogenous stress factors influence.
\end{abstract}

Keywords: Chara fragilis, $\mathrm{H}^{+}$-pumps, $\mathrm{K}^{+}$-channels, membrane potential, membrane resistance, plasmalemma, TEA ${ }^{+}$-iodide, vanadate

Submitted 23 December 2019. Published 31 October 2020

Хасанова А.Е. ${ }^{1}$, Мусаєв Н.А. ${ }^{2}$ 2020. Біоелектричні характеристики клітин Chara fragilis (Characeae). Український ботанічний журнал, 77(5): 398-404.

${ }^{1}$ Інститут ботаніки, Національна академія наук Азербайджана

Бадамдарське шосе, 40 Баку AZ1004, Азербайджан

${ }^{2}$ Відділ біофізики та молекулярної біології, Бакинський державний університет

вул. Академіка Західа Халілова, 23, Баку AZ1148, Азербайджан

Реферат. За допомогою методу Хогга вперше отримані дані з розподілу потенціалу $\left(\varphi_{\mathrm{m}}\right)$ та опору $\left(\mathrm{R}_{\mathrm{m}}\right)$ плазматичної мембрани та клітинної стінки $\left(\mathrm{R}_{0}\right)$ клітин Chara fragilis у стандартних умовах за кількістю клітин C. fragilis. Метод Хогга дозволяє одночасно вимірювати електрофізіологічні параметри $\varphi_{\mathrm{m}} \mathrm{i} \mathrm{R}_{\mathrm{m}}$. Стаціонарні значення мембранного потенціалу та опору варіювали в досить широкому діапазоні: $-90 \ldots-300 \mathrm{mB}$ та $1,0 \ldots 32,6$ Ом м $^{2}$, відповідно. Середнє значення $\varphi_{\mathrm{m}}$ становило $-183,0 \pm 4,9 \mathrm{MB}, \mathrm{R}_{\mathrm{m}}-9,0 \pm 1,2 \mathrm{Oм}^{\cdot} \mathrm{m}^{2}$. Із застосуванням стандартних модифікаторів мембранного транспорту здійснена диференціація електрогенної активності клітин на два типи: $\mathrm{K}^{+}$-каналів та Н $\mathrm{H}^{+}$-мембранних насосів. Діапазони активації $\mathrm{K}^{+}$-каналів внутрішнього та зовнішнього випрямлення становили $-130 \ldots-50$ та $-300 \ldots-162$ мВ відповідно, цитозольна активність $\mathrm{K}^{+}$-іонів - 61,6 ммоль/л. Оскільки в наших дослідженнях клітини C. fragilis використовувалися вперше, перевірялася їхня електрогенна активність та іонна провідність 3 використанням метаванадату амонію (VOз ) - інгібітора протонної помпи та тетраетиламонію $\left(\mathrm{TEA}^{+}\right)$- універсального блокатора $\mathrm{K}^{+}$-каналів плазматичних мембран. Клітини C. fragilis можуть бути рекомендовані як тест-об'єкт для встановлення механізмів зміни мембранного транспорту в плазматичній мембрані під впливом екзогенних чинників та стресових факторів.

Ключові слова: Chara fragilis, $\mathrm{H}^{+}$-насоси, $\mathrm{K}^{+}$-канали, ванадат, мембранний опір, мембранний потенціал, плазмалема, $\mathrm{TEA}^{+}$-йодид

(C) 2020 A.E. Hasanova, N.A. Musayev. Published by the M.G. Kholodny Institute of Botany, NAS of Ukraine. This is an open access article under the terms of the Creative Commons Attribution License (http://creativecommons.org/licenses/by/4.0/), which permits use, distribution, and reproduction in any medium, provided the original work is properly cited 


\section{Introduction}

Experimental studies of Chara algae contributed to establishing the components and kinetic characteristics of primary active transport in the plasma membrane of plant cells (Yurin et al., 1991; Véry, Sentenac, 2003; Volkov, 2006), and to revealing the mechanisms of modification of membrane transport by a number of xenobiotics, pharmacological agents, etc. (Musayev et al., 2009; Musayev, 2012). The application of Chara algae as a test object is not restricted to the study of cellular mechanisms of the above listed exogenous stimuli action. Isolated Chara cells are a very promising tool for detecting adaptive reactions during the modification of membrane transport in the plasma membrane under stress (Demidchik, 2012). To this end, the involvement of new objects with different electrochemical and kinetic characteristics could stimulate identifying meaningful patterns of the response of isolated cells and plants in general to exogenous stimuli. This paper describes the bioelectric parameters of the cells of Chara fragilis Desvaux, which we first introduced into the electrophysiological practice. Using specific modifiers of the transport properties of the plasma membrane, the components of the primary active transport and electrogenic activity of $C$. fragilis cells were identified.

The use of vanadate, an inhibitor of $\mathrm{H}^{+}$-pumps (Opritov, 2000; Larskaya, Zabotin, 2001), could provide valuable information about the possible interactions of the two components of the ion transport system in the plasma membrane of plant cells $-\mathrm{H}^{+}$-pumps and $\mathrm{K}^{+}$channels. Such studies are especially important for cells of freshwater alga $C$. fragilis, since so far there is insufficient information about transport properties of the plasma membrane of these cells (Hasanova et al., 2017). Thereby this work is devoted to the study of the electrogenic and diffusion properties of the plasma membrane of $C$. fragilis under the influence of different concentrations of ammonium vanadate. The aim of the work is to monitor the state of $\mathrm{K}^{+}$-channels at inhibition of the electrogenic transport implemented by the $\mathrm{H}^{+}$pumps of the plasmalemma.

The established facts indicate a close relationship between the two main components of the ion transport system of the plasma membrane, can be used in constructing a general theory of the interaction of xenobiotics with biological membranes. The high sensitivity of $C$. fragilis cells to low concentrations of the inhibitor can be used for express diagnostics of the ion transport system of plant cells.

\section{Materials and methods}

The object of the study was the alga Chara fragilis found in a small pond, a collector of sewage from a number of mountain springs, on the territory of "Katib Bulagy" in the Tovuz Region of the Azerbaijan Republic. Chara fragilis belongs to the family Characeae Ag. emend. Hollerb. of the Charophyceae class. Taxonomic position of the alga was identified by its anatomical and morphological characteristics using the Guide to FreshWater Algae of the USSR (Gollerbach, Krasavina, 1983), with the kind support of the algologists of the Institute of Botany, National Academy of Sciences of Azerbaijan.

The length of mature internodal cells of $C$. fragilis reached $6-11 \mathrm{~cm}$ with $0.3-1.0 \mathrm{~mm}$ diameter. Due to the large size, the internodal cells of $C$. fragilis may be used for several days in the microelectrode assays. The mineral composition of the "Katib Bulagy" water was determined by atomic absorption spectroscopy AAS-1 spectrophotometer company Bruker, Germany, corresponded to the mineral composition of artificial pond water (APW), containing $0.1 \mathrm{M} \mathrm{K}^{+}, 1 \mathrm{M} \mathrm{Na}^{+}$, $0.4 \mathrm{M} \mathrm{Ca}^{2+}, 0.3 \mathrm{M} \mathrm{Mg}^{2+}$-cations and $\mathrm{Cl}^{-}, \mathrm{HCO}^{3-}, \mathrm{NO}^{3-}$, $\mathrm{PO}_{4}^{3-}, \mathrm{SO}_{4}^{2-}$-anions at $\mathrm{pH}$ 6.9-7.2 (Hasanova et al., 2017). Plants harvested from the "Katib Bulagy" pond were well adapted to laboratory conditions. Plants were grown on $\mathrm{APW}$, in aquariums with $0.3 \times 0.4 \times 0.5 \mathrm{~m}$ dimension under room light conditions (with intensity $6 \mathrm{~W} / \mathrm{m}^{2}$ ) 12-14 hours per day. The optimal temperature ranges for growing $C$. fragilis was $18-23{ }^{\circ} \mathrm{C}$. Increasing the temperature of growing medium to $30^{\circ} \mathrm{C}$ and higher was lethal for the plants.

The cells no longer than $20 \mathrm{~mm}$ in length were used in the experiments to ensure the high accuracy of membrane resistance measurement. This value corresponded to the length of the second cell from the top of the $C$. fragilis plants. The day before the experiments, an intranodal cell of $C$. fragilis, second from the top, was separated from neighbor internodes and placed in Petri dish with a standard nutrient medium. It was necessary for an accurate assessment of the direction of fluxes and gradients of electrochemical potentials. To measure the main electrophysiological parameters (the membrane resistance $\mathrm{R}_{\mathrm{m}}$, the potential $\varphi_{\mathrm{m}}$ of the plasma and vacuolar membranes) we used the two-electrode Hogg method (Hogg et al., 1968) developed for cells having a cylindrical shape. The Hogg method made it possible to simultaneously register the membrane potential $\varphi_{\mathrm{m}}$ and resistance $\mathrm{R}_{\mathrm{m}}$ in algal cells for many hours. The direct current pulses with a density of $10^{-4}$ 
$\mathrm{A} / \mathrm{m}^{2}$ in a duration of $2-3$ seconds was transmitted through one microelectrode introduced into the center of the cell. Values $\varphi_{\mathrm{m}}$ and the electrotonic potential $\Delta \mathrm{U}$ generated by passing a direct current through the cell was recorded via the second microelectrode. We also carried out a measurement of the current passing through the middle of the experimental cell. The numerical value of the current was determined by the voltage drop at the etalon resistance, connected in series with the experimental cell in the current circuit. $\mathrm{R}_{\mathrm{m}}$ of cells is calculated by the formula

$$
\mathrm{R}_{\mathrm{m}}=\frac{\Delta \mathrm{U}}{\mathrm{I}} \pi \mathrm{dl}
$$

where I - current transmitted through the middle of the cell, $1, \mathrm{~d}$ - length and diameter of the experimental cell.

APW was used as a solvent in the preparation of working solutions of inhibitors and blockers. Cells were treated with inhibitors or blockers in the measuring chamber during measurement, not in Petri dishes. The growth medium (APW) or working solution was regularly introduced into the corresponding part of the measuring chamber using thin (1.5 $\mathrm{mm}$ diameter) silicone tubes (inflow tube), and then removed using these tubes (outflow duct). To treat cells with APW modifiers in the measuring chamber, they were replaced with appropriate solutions.

Statistical processing of experimental results was carried out according to the laws of variation statistics (Lakin, 1990) using of computer programs Excel-2016 and SigmaPlot 12.0.

\section{Results}

\section{Statistical analysis of the electrophysiological parameters of Chara fragilis cells under standard conditions}

Since the $C$. fragilis cells were first introduced by us in the practice of electrophysiological research, we needed to conduct a statistical analysis of the distribution of electrophysiological parameters by the number of cells in standard conditions. It was found that the stationary values of $\varphi_{\mathrm{m}}$ and $\mathrm{R}_{\mathrm{m}}$ varied in a rather wide range: $-90 \ldots$ $-300 \mathrm{mV}$ and $1.0-32.6 \mathrm{Ohm} \cdot \mathrm{m}^{2}$, respectively. The average value of $\varphi_{\mathrm{m}}$ was $-183.0 \pm 4.9 \mathrm{mV}$. The sample size $\mathrm{m}$ of the experimental material was 106. The distribution of $\varphi_{\mathrm{m}}$ obeyed to the Gauss - Moivre - Laplace law of normal distribution. The value of the membrane resistance, which is calculated from the resistance level of the cell membrane, was $9.0 \pm 1.2 \mathrm{Ohm} \cdot \mathrm{m}^{2}(\mathrm{~m}=45)$. The distribution of the set of values of $R_{m}$ did not obey the law of normal distribution. The distribution curve compresses on the right. The majority of cells were characterized by less resistance (more conductivity).

Upon contact of the measuring microelectrode tip with the cell membrane under standard environmental conditions, a signal was recorded which value was $\varphi_{0}=-30.0 \pm 2.5 \mathrm{mV}(\mathrm{m}=28)$. It represents the potential of the cell membrane relative to the environment, and this value is commonly called the potential of the cell wall. By passing current through the cell with a current microelectrode, on the cell wall a voltage drop was recorded $\Delta \mathrm{U}_{0}$, by which the value of its resistance $\mathrm{R}_{0}=$ $3.8 \pm 0.7 \mathrm{Ohm} \cdot \mathrm{m}^{2}(\mathrm{~m}=28)$ was calculated.

The number of classes was determined by the formula proposed by Brooks and Caruzer and amounted 10. The sample size $m$ of the experimental material was 106, the class interval $\mathrm{i}=21 \mathrm{mV}$. Therefore, we presented the variational series $\varphi_{\mathrm{m}}$ as a distribution of the total volume between 11 classes (Fig. 1). The variational series of $\varphi_{\mathrm{m}}$, represented as a histogram, had a maximum at $-174 \mathrm{mV}$.

The estimation of this value, according to our empirical data, yielded $\chi^{2}=16.75$. And the theoretical value of critical value for the $0.5 \%$ significance level was 16.75 , i.e. $\chi^{2}=\chi_{\mathrm{kr}}^{2}$ This means that the distribution of $\varphi_{\mathrm{m}}$ in classes corresponds to the normal distribution.

The reached stationary levels of $\varphi_{\mathrm{m}}$ and $\mathrm{R}_{\mathrm{m}}$ under standard conditions were stable for several hours. Spontaneous transitions of $\varphi_{\mathrm{m}}, \mathrm{R}_{\mathrm{m}}$ to other levels were not detected.

Similar calculations were made for the membrane resistance. The distributions of the empirical and theoretical frequencies sharply differed among themselves. The distribution of the set of values of $\mathrm{R}_{\mathrm{m}}$ did not obey the law of normal distribution. There was no correlation between $\varphi_{\mathrm{m}}$ and $\mathrm{R}_{\mathrm{m}}$. The correlation coefficient between these values was $r=-0.019878$. In the total set of cells, proportion of cells with increased conductivity dominated.

\section{Electrogenic activity and conductibility of plasma membrane in Chara fragilis cells under influence of vanadate}

The next step in our research was testing the limits of the electrogenic activity of the $\mathrm{H}^{+}$-pumps and the conductivity of $\mathrm{K}^{+}$-channels of the plasma membrane using the appropriate modifiers. The electrogenic composing of the membrane potential was determined using vanadate, 


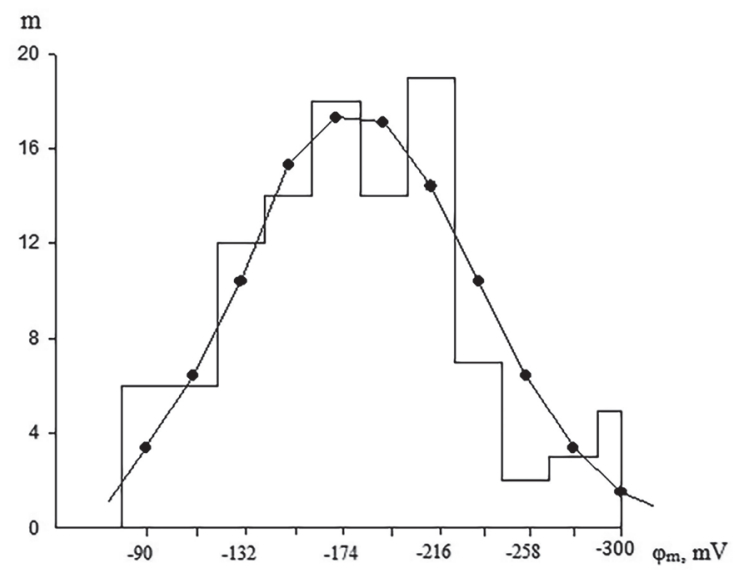

Fig. 1. Histogram of the membrane potential $\varphi_{\mathrm{m}}$ distribution of the Chara fragilis by the number of cells $(\mathrm{m})$. The figure shows the theoretical frequencies calculated from the variation statistics of the dotted variants. A continuous line shows the calculated normal distribution

a common inhibitor of $\mathrm{H}^{+}$-pumps of plasmalemma. The minimum concentration of the inhibitor, which caused a noticeable depolarization of the plasmalemma, was $10^{-5} \mathrm{M}$. An increase of its concentration in the medium up to $10^{-3} \mathrm{M}$, led to the depolarization of the plasmalemma to $80-100 \mathrm{mV}$ within $30-60 \mathrm{~min}$ (Fig. 2).

In $89 \%$ of the cells of the total population, $\mathrm{VO}_{3}^{-}$-induced depolarization of the plasma membrane was accompanied by a monotonic decrease of the $\mathrm{R}_{\mathrm{m}}$. The relative decrease in $\mathrm{R}_{\mathrm{m}}$ in these cells under the influence of a $10^{-4} \mathrm{M}$ inhibitor for 33-30 minutes was 33\%, but under the influence of the most effective concentration of the inhibitor $10^{-3} \mathrm{M}$ was $14 \%$ (Fig. 2).

The removal of the inhibitor from the solution of artificial pond water was accompanied by the restoration of the $\varphi_{\mathrm{m}}, \mathrm{R}_{\mathrm{m}}$ values in the investigated cells. However, $\varphi_{\mathrm{m}}$, as a rule, was restored to levels exceeding the initial level on $36 \mathrm{mV}$. On the contrary, under normal environmental conditions after inhibitory treatment, the final $\mathrm{R}_{\mathrm{m}}$ levels of of the investigated cells processing were $7-8 \%$ lower than the initial values (Fig. 2).

Electrophysiological analysis of changes in the kinetics of $\varphi_{\mathrm{m}}$ and $\mathrm{R}_{\mathrm{m}}$ in Chara fragilis cells under the influence of tetraethyl ammonium

To test the electrogenic activity of $C$. fragilis cells while reducing the shunt load of $\mathrm{H}^{+}$-pumps of plasma membrane, we used in our measurements iodide salt of tetraethyl ammonium $\left(\mathrm{TEA}^{+}\right)-$a blocker of all types of $\mathrm{K}^{+}$-channels. The minimum concentration of the blocker that caused the primary bioelectric response of the cells

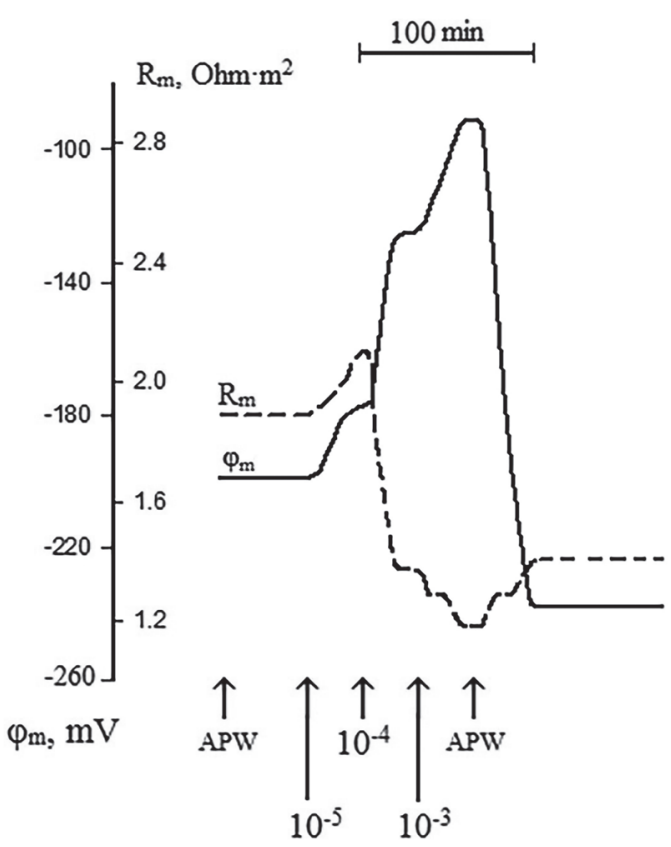

Fig. 2. The potential $\varphi_{\mathrm{m}}$ and resistance $\mathrm{R}_{\mathrm{m}}$ of the plasma membrane of Chara fragilis cells in the presence of vanadate. The arrows indicate the moments of the appropriate concentrations (molar) addition in the nutrient medium (APW). Cell size: length $7.1 \mathrm{~mm}$, diameter $0.325 \mathrm{~mm}$

was $10^{-7} \mathrm{M}$ in the medium. The electrophysiological reaction of the plasma membrane of $C$. fragilis was rather complicated in the presence of different blocker concentration in the medium (Fig. 3).

\section{$\mathrm{K}^{+}$-characteristics of Chara fragilis cells}

The dependences of $\varphi_{\mathrm{m}}$ and $\mathrm{R}_{\mathrm{m}}$ on the $\mathrm{K}^{+}$-concentration in the medium were illustrated by three-phase curves (Fig. 4). The first phase of the dependence in the range of $\varphi_{\mathrm{m}}-300 \ldots-165 \mathrm{mV}$ probably shows the activation of $\mathrm{K}^{+}$-channels of inward rectification (KCIR), and the third phase in the range of $\varphi_{\mathrm{m}}-120 \ldots-50 \mathrm{mV}-$ $\mathrm{K}^{+}$-outward rectifying channels (KCOR). The second phase can probably be called a transition phase, because presumably the partial inactivation of the $\mathrm{K}^{+}$-inward rectifying channels and activation of the $\mathrm{K}^{+}$-outward rectifying channels occur in this phase.

For the other Chara species, the $\mathrm{K}^{+}$-equilibrium potential in a medium with $10^{-4} \mathrm{M} \mathrm{K}^{+}$corresponded to the boundary range of the activation for two kinds of $\mathrm{K}^{+}$-channels. According to it, $\varphi_{\mathrm{m}}$ for $C$. fragilis is -162 $\mathrm{mV}$ (Fig. 4). In view of this value, the intracellular activity of $\mathrm{K}^{+}$-ions $\left(\mathrm{a}_{\mathrm{K}^{+}}\right)$can be calculated from the Nernst formula, which was $61.6 \mathrm{mmol} / \mathrm{L}$. 


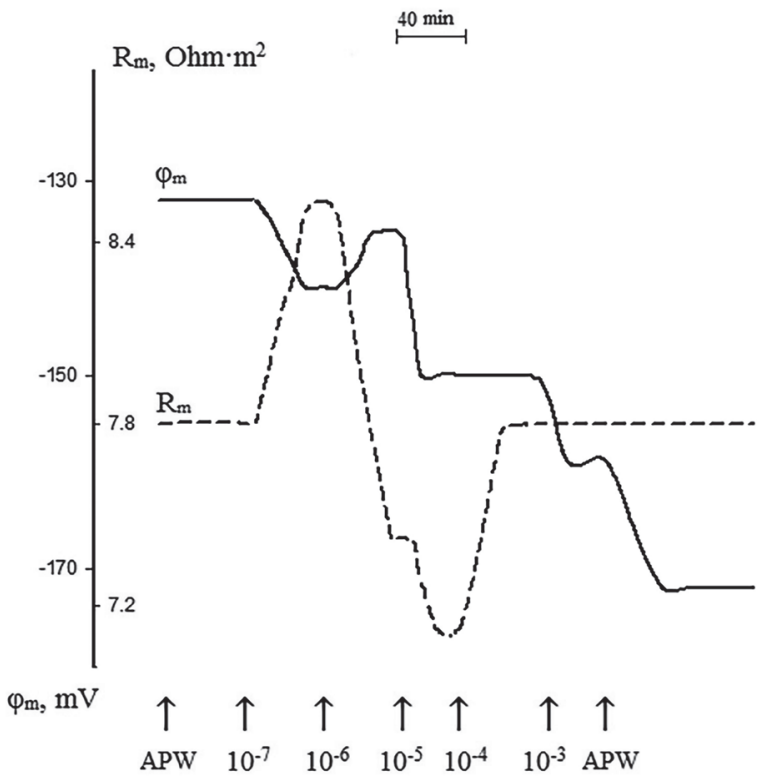

Fig. 3. Changes of the potential $\varphi_{\mathrm{m}}$ and resistance $\mathrm{R}_{\mathrm{m}}$ of the plasma membrane of the Chara fragilis cells with a progressive increase in $\mathrm{TEA}^{+}$-iodide concentration $10^{-7}-10^{-3} \mathrm{M}$ in the nutrient medium. The arrows indicate the moments of the appropriate concentrations (molar) addition in the nutrient medium (APW). Cell size: length $10.6 \mathrm{~mm}$, diameter $0.45 \mathrm{~mm}$

\section{Discussion}

The established ranges of $\varphi_{\mathrm{m}}$ reflecting the conductivity states of the two types of $\mathrm{K}^{+}$-channels are consistent with the analogous parameters of other species of Characeae: Nitella flexilis (Musayev et al., 2008; Musayev, 2012), Chara gymnophylla (Sokolik, Yurin, 1986; Musayev, Ismailov, 2007) and Nitellopsis obtusa (Musayev, 2012). For these cells, the measured $\mathrm{K}^{+}$-equilibrium potential in a medium with $10^{-4} \mathrm{M} \mathrm{K}^{+}$-corresponded to the boundary of the activation ranges for two kinds of $\mathrm{K}^{+}$-channels. According to this position, $\varphi_{k}$ for Chara fragilis is -162 $\mathrm{mV}$ (Fig. 4). In view of this value, the intracellular activity of $\mathrm{K}^{+}$-ions $\left(\mathrm{a}_{\mathrm{k}}\right)$ can be calculated from the Nernst formula, which was $61.6 \mathrm{mmol} / \mathrm{L}$. The obtained value of $\mathrm{a}_{\mathrm{k}}$ is much lower than in Nitellopsis optusa cells (Musayev, 2012). However, it is comparable to the value of $\mathrm{a}_{\mathrm{k}}$ established for another species of Chara C. gymnophylla (70 mmol/L) (Musayev, Ismailov, 2005).

The electrogenic composing of the membrane potential was determined using vanadate - a common inhibitor of $\mathrm{H}^{+}$-pumps of plasmalemma. The inhibitor has been most effective in concentration $10^{-3} \mathrm{M}$. The addition of an inhibitor at this concentration to the standard medium caused depolarization of the plasma membrane by $-170 \ldots-180 \mathrm{mV}$ in cells with the initial

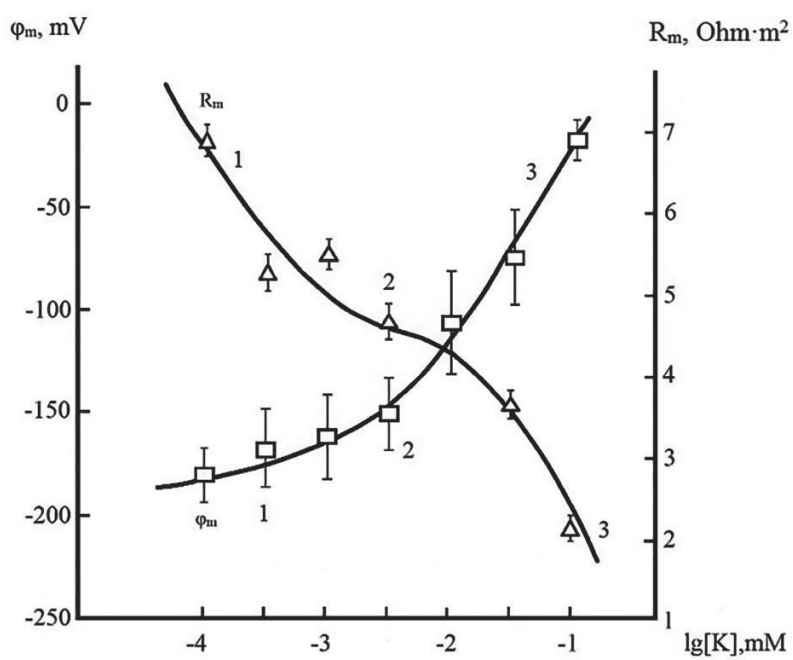

Fig. 4. Dependence of stationary values of $\varphi_{m}$ and $R_{m}$ of the PM of Chara fragilis cells on the concentration of $\mathrm{KCl}$ in the APW. The marks 1,2, 3 on the curves indicate the particular phases of change of the corresponding values. Each point reflects the average of the measured values of $\varphi_{m}$ and $R_{m}$ for 9-10 cells. Vertical lines indicate the standard deviation of the mean of $\varphi_{\mathrm{m}}$ and $\mathrm{R}_{\mathrm{m}}$

$\varphi_{\mathrm{m}}=-250 \mathrm{mV}$ (Fig. 2). This indicates a significant contribution of $\mathrm{H}^{+}$-pumps to the electrogenic activity of the plasma membrane of $C$. fragilis. The decrease $\mathrm{R}_{\mathrm{m}}$ on the background of progressive depolarization of the plasma membrane represents the massive activation of $\mathrm{K}^{+}$-outward rectifying channels, that was also found in C. gymnophylla cells (Musayev et al., 2008).

For testing the electrogenic activity of $C$. fragilis with a decrease in the shunt load of $\mathrm{H}^{+}$-pumps of plasma membrane, we used iodide salt of tetraethyl ammonium $\left(\mathrm{TEA}^{+}\right)$- a blocker of all types of $\mathrm{K}^{+}$-channels (Yurin et al., 1991). The minimum concentration of the blocker that caused the primary bioelectric response in the cells was $10^{-7} \mathrm{M}$. The electrophysiological reaction of C. fragilis plasma membrane was rather complicated in the presence of different blocker concentration in the medium (Fig. 3). When analyzing the kinetics of the electrophysiological reaction, it is necessary to consider the multifacetedness of the blocking action of $\mathrm{TEA}^{+}$. In the cells of Nitella flexilis (Vysotskaya et al., 2005) and C. gymnophylla (Musayev, Vorobev, 1983), $\mathrm{TEA}^{+}$-blocking of $\mathrm{K}^{+}$-channels led to stimulation of the $\mathrm{H}^{+}$-pump of the plasma membrane and reduction of its integral resistance. Earlier, we also observed changes in the structural-polarization state in the cells of Nitellopsis obtuse under the influence of the blocker (Musayev, Vorobev, 1983). 
The distribution of the potential and resistance by the number of cells indicates that a significant part of the total number is composed of cells with high electrogenic activity.

\section{Conclusion}

Based on the results reported in this study, it can be proposed that the interstitial cells of Chara fragilis with stable electrophysiological parameters can serve as a new promising object for the investigation of the membranotropic actions of exogenous stimuli, including xenobiotics, nanoparticles, phytoprotectors, pharmacological agents, etc. Established dependencies of the resistance and potential of the plasma membrane on the concentration of $\mathrm{K}^{+}$in the medium made it possible to identify the ranges of the membrane potential within which the $\mathrm{K}^{+}$-channels of the inward or outward rectification are in the conducting state. Inhibitory analysis allowed to determine the proportion of the electrogenic component in the total membrane potential. Accordingly, the differentiation of the membrane potential into $\mathrm{K}^{+}$-channels and $\mathrm{H}^{+}$-pumps was implemented. Significant values of the potential and resistance of the cell membrane allow the using of isolated $C$. fragilis cells for studying the ion-exchange properties of the plant cell membranes.

\section{References}

Demidchik V.V. 2012. Membrane mechanisms of regulation of the activity of calcium ions in the cytoplasm of cells of higher plants. Proceedings of the BSU. Series Physiological, biochemical and molecular basis of biosystems, 7(1): 99-105. [Демидчик В.В. 2012. Мембранные механизмы регуляции активности ионов кальция в цитоплазме клеток высших растений. Труды БГУ. Серия Физиологические, биохимические и молекулярные основы биосистем, 7(1): 99-105].

Gollerbach V.I., Krasavina L.K. 1983. Key to freshwater algae of the USSR. Leningrad: Nauka, 185 рр. [Голлербах В.И., Красавина Л.К. 1983. Определитель пресноводных водорослей СССР. Ленинград: Наука, 185 с.].

Hasanova A., Najafaliyeva Sh., Aliyeva P., Musayev N. 2017. Chara fragilis cells - a new object for electrophysiology research. Journal of Baku Engineering University Chemistry and Biology, 1(2): 176-182.

Hogg J., Williams E.J., Jhonston R.I. 1968. A simplified method for measuring membrane resistances Nitella translucens. Biochemistry et Biophysics Acta, 150: 1-518.

Lakin G.F. 1990. Biometrics. Moscow: Visshaya Shkola, 352 pр. [Лакин Г.Ф. 1990. Биометрия. Москва: Высшая школа, 352 с.].
Larskaya I.A., Zabotin A.I. 2001. The study of changes in the activity of the proton pump of the plasmalemma during lowtemperature hardening of winter wheat seedlings. Bulletin of the Bashkir University, 2: 87-90. [Ларская И.А., Заботин А.И. 2001. Исследование изменения активности протонный помпы плазмалеммы при низкотемпературном закаливании проростков озимой пшеницы. Вестник Башкирского университета, 2: 87-90].

Musayev N.A., Vorobev L.N. 1983. The state of the $\mathrm{K}^{+}-$ channels of the membranes of plant cells and the regulation of their photoelectric activity. Izvestiya AN AzSSR. Series Biological Sciences, 3: 91-101. [Мусаев Н.A., Воробьев Л.Н. 1983. Состояние К ${ }^{+}$-каналов мембран растительных клеток и регулирование их фотоэлектрической активности. Известия $А Н A_{3} C C P$. Серия биологические науки, 3: 91-101] .

Musayev N.A., Ismailov E.R. 2005. Bioelectric characteristics of Chara gymnophylla cells. Izvestiya NAS of Azerbaijan. Series Biological Sciences, 3-4: 196-214. [Мусаев Н.А., Исмаилов Э.Р. 2005. Биоэлектрические характеристики клеток Chara gymnophylla. Известия НАН Азербайджана. Серия биологические науки, 3-4: 196-214].

Musayev N.A., Ismailov E.R. 2007. Bioelectrical properties of Chara gymnophylla plasmamembrana during interaction with cobalt $\left(\mathrm{Co}^{2+}\right)$. Ecoloji, 63: 1-6.

Musayev N.A., Yurin V.M., Sokolik A.I., Ismailov E.R. 2008. Electrogenic activity of the plasma membrane of Chara gymnophylla cells when $\mathrm{K}^{+}$-channels are blocked by tetraethylammonium. Bulletin of Belorus State University, 2(2): 46-49. [Мусаев Н.А., Юрин В.М., Соколик А.И., Исмаилов Э.Р. 2008. Электрогенная активность плазматической мембраны клеток Chara gymnophylla при блокировании $\mathrm{K}^{+}$-каналов тетраэтиламмонием. Вестник Белорусского государственного универсиmema, 2(2): 46-49.]

Musayev N.A., Yurin V.M., Sokolik A.I. 2009. Potential, resistance and electric capacity of the plasma membrane of Nitellopsis obtusa cells under the action of diethylstilbestrol. Trudy Belaruskogo gosudarstvennogo universita. Series Physiological, Biochemical and Molecular Foundations of the Functioning of Biosystems, 4(1): 74-78. [Мусаев Н.А., Юрин В.М., Соколик А.И. 2009. Потенциал, сопротивление и электрическая ёмкость плазматической мембраны клеток Nitellopsis obtusa при действии диэтилстилбестрола. Tpydbl Белорусского государственного университета. Серия Физиологические, биохимические и молекулярные основы функиионирования биосистем, 4(1): 74-78].

Musayev N.A. 2012. Biophysical mechanisms for modifying the transport properties of the plasma membrane of plant cells: Dr. Sci. Diss. Baku, Institute of Botany, 334 pp. [Мусаев Н.А. 2012. Биофизические механизмы модификации транспортных свойств плазматической мембраны растительных клеток: дис. ... д-ра биол. наук: 03.00.02. Баку, Институт ботаники, 334 с.].

Opritov V.A. 2000. $\mathrm{H}^{+}$-ATPase of the plasma membrane is the main electrogenic system of higher plants. Biology, 6(2): 
28-32. [Опритов В.А. 2000. Н ${ }^{+}$-АТФаза плазматической мембраны - основная электрогенная система высших растений. Биология, 6(2): 28-32].

Sokolik A.I., Yurin V.M. 1986. Potassium channels in plasmalemma of Nitella cells at rest. Journal of Membran Biology, 89(1): 9-22.

Véry A., Sentenac H. 2003. Molecular mechanisms and regulation of $\mathrm{K}^{+}$-transport in higher plants. Journal of Annual Review of Plant Biology, 54: 575-603.

Volkov G.A. 2006. Plant Electrophysiology: Theory and methods. New York: Springer-Verlag, 264 pp.

Vysotskaya J.V., Sokolik A.I., Yurin V.M. 2005. The interaction of ion transport mechanisms on the plasma membrane of plant cells: potassium channels and a hydrogen pump. Vestnik Belorusskogo gosudarstvennogo universiteta. Seriya 2, Khimiya. Biologiya. Geografiya, 2: 50-54. [Высоцкая Ж.В., Соколик А.И., Юрин В.М. 2005. Взаимодействие механизмов ионного транспорта на плазматической мембране растительных клеток: калиевые каналы и электрогенная водородная помпа. Вестник Белорусского государственного университета. Серия 2, Химия. Биология. География, 2: 50-54].

Yurin V.M., Sokolik A.I., Kudryashov A.P. 1991. Regulation of ion transport across plant cell membranes. Minsk: Nauka i tekhnika, 272 pp. [Юрин В.М., Соколик А.И., Кудряшов А.П. 1991. Регуляция ионного транспорта через мембраны растительных клеток. Минск: Наука и техника, 272 с.].

Recommended for publication by I.V. Kosakivska 